AUTHOR CORRECTION OPEN

\title{
Author Correction: Identification and targeting of an FGFR fusion in a pediatric thalamic "central oligodendroglioma"
}

Joseph R. Linzey ${ }^{1}$, Bernard Marini ${ }^{2}$, Kathryn McFadden ${ }^{3}$, Adonis Lorenzana ${ }^{4}$, Rajen Mody ${ }^{1}$, Patricia L. Robertson ${ }^{5}$ and Carl Koschmann ${ }^{1}$ npj Precision Oncology (2018)2:12; doi:10.1038/s41698-018-0054-1

Correction to: npj Precision Oncology 1:29; https://doi.org/ 10.1038/s41698-017-0036-8, Published online: 07 September 2017

In the original version of this Article the Supplementary Information was missing. This file has now been added to the HTML version of this Article.

Open Access This article is licensed under a Creative Commons Attribution 4.0 International License, which permits use, sharing adaptation, distribution and reproduction in any medium or format, as long as you give appropriate credit to the original author(s) and the source, provide a link to the Creative Commons license, and indicate if changes were made. The images or other third party material in this article are included in the article's Creative Commons license, unless indicated otherwise in a credit line to the material. If material is not included in the article's Creative Commons license and your intended use is not permitted by statutory regulation or exceeds the permitted use, you will need to obtain permission directly from the copyright holder. To view a copy of this license, visit http://creativecommons. org/licenses/by/4.0/.

(c) The Author(s) 2018

\footnotetext{
${ }^{1}$ Department of Pediatrics, Division of Pediatric Hematology/Oncology, University of Michigan Medical School, Ann Arbor, MI 48109, USA; ${ }^{2}$ Department of Pharmacy Services,

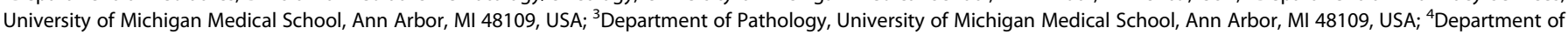
Pediatric Hematology-Oncology, St. John's Hospital Grosse Pointe Woods, Detroit, MI 48236, USA and ${ }^{5}$ Department of Pediatrics, Division of Neurology, University of Michigan Medical School, Ann Arbor, Ml 48109, USA

Correspondence: Carl Koschmann (ckoschma@med.umich.edu)
}

Published online: 25 April 2018 